\section{EUROPEAN SPACE}

\section{Success and Fuilure}

THE past few weeks have seen some ironical developments for European and British space research. Britain, which no longer wants a national launch vehicle, now has one, and ELDO is still without the launcher which is the chief purpose for its existence. The avowed British policy of depending on the United States for future launch facilities, both for scientific and technological satellites, has, however, now been vindicated (at least partially). At last, the anomaly of continuing with this inadequate British launcher, contributing to ELDO and planning to make increasing use of American facilities has been resolved, and the situation is now less confused than at any time since Britain joined ELDO while at the same time developing Black Arrow.

Black Arrow's successful launch, on October 28, and the failure of Europa II on November 5 lend weight to the British decision to stop financial support for ELDO. Coming only a few days after the announcement that the US State Department has now agreed in principle to provide launch facilities for research, meteorology, navigation, telecommunication and Earth resources satellites, the most recent failure may well sound the death knell for ELDO. The only members of the organization still enthusiastic about an independent European launcher are France and Germany, who may proceed with a binational programme aimed at providing a launcher for Symphonie.

Just what did go wrong with Europa II? It is too soon to be sure, but indications are that the failure-possibly an explosion-occurred $150 \mathrm{~s}$ after take-off in the first stage, Britain's Blue Streak. This is the only stage which has never failed on previous ELDO launches. But the rocket's navigation system also failed, before the explosion and, apparently, independently of it. A second explosion, in the French Coralie second stage, may have been triggered by the Blue Streak failure. It is a sobering thought that roughly 100 proved American launchers could have been bought for the $£ 250$ million spent by ELDO so far.

The future for European satellites, however, looks brighter than the gloomy launcher position might indicate. For although it has been clear for years that because the cost per launch decreases as a vehicle is used more, American launchers are and will remain cheaper than European launchers can hope to be. Until last week there was no firm promise that such launchers would be available except for scientific satellites or for projects with a large American interest, such as Intelsat. There are, however, no apparent strings attached to the new promise, although it may well be intended to create an atmosphere of cooperative goodwill towards the shuttle project.

\section{BRUCELLOSIS}

\section{Towards Clean Cows}

IN its campaign to wipe out brucellosis, an infectious disease that causes spontaneous abortion in cows and undulant fever in people, the Ministry of Agriculture last week restricted cattle movements in certain areas of Great Britain.

Although vaccination for calves has been available since the 1940s, the first real steps were taken in April 1967 with the introduction of the Brucellosis (Accredited Herds) Scheme which built up a register of herds free from brucellosis, chiefly to be used as replacement cattle for later stages of eradication. In July 1970, the Brucellosis Incentives Scheme was introduced, which provides financial inducements of $£ 0.008$ per gallon of milk for brucellosis-free dairy cattle and $£ 5$ a head in addition to the hill cow and beef cow subsidy. Both these schemes are voluntary and aimed at attracting owners of herds with light to moderate infection to build up the numbers of brucellosis-free cattle. The subsidies are paid for a five year period and one of the conditions of the scheme is that animals found to be infected are slaughtered. In November 1972, compulsory slaughter will be introduced for infected animals in those areas now subject to movement restrictions--parts of north-west England, west Scotland, south-west Wales and the Isle of Wight. Farmers in compulsory eradication areas receive $£ 30$ in compensation for a slaughtered animal, provided that the free calf vaccination service has been used since July of this year. If the service has not been used, $£ 15$ will be paid, with market value being paid for any slaughtered "contacts" (the market value of a dairy shorthorn at the end of October was £111.50). Gradually the eradication areas will be extended until the disease can, it is hoped, be effectively wiped out.

Brucellosis is not a notifiable disease and it is therefore difficult to discover how many cases there are in Britain and how much it costs the country each year. A ministry survey of 3,000 herds in 1961 suggested that between 25 and 30 per cent of herds were infected but the survey only covered dairy herds and no figures for beef herds seem to be available. In 1967 it was estimated that 14 per cent of cattle would react to brucellosis tests and in August this year a Milk Marketing Board survey over six months, using milking tests and covering every herd with which the board deals, showed that 28.5 per cent of herds contained reactors. A limited survey in Lancashire in 1970 , also by the board, showed that 18 per cent of cattle reacted. There were 717 reported cases in humans in the United Kingdom and Eire last year, but it is thought that there were hundreds more either not reported or not diagnosed.

Estimates of the cost are equally vague, but a figure of $£ 2$ million to $£ 3$ million for the cost to the industry and of about $£ 16$ million to the country would seem reasonable, although the latter figure particularly is disputed.

The Ministry of Agriculture puts no official figure on the cost of eradicating the disease but something in the order of $£ 100$ million is a fair estimate. The size of this figure may account for the length of time it has taken Britain to begin eradication --some continental countries have virtually beaten the disease already, and a draft EEC regulation rules that after December 1975 no milk will be accepted from brucellosisinfected herds. The lion's share of the cost will be in compensation and incentives to farmers over the next few years. How long eradication will take depends upon a number of factors, not least the willingness of farmers to cooperate, but it is hoped to beat brucellosis in ten to fifteen years. This compares with the twenty-five years it took to remove bovine tubercuiosis from $1935-60$ at a cost of $£ 130$ million.

The eradication of the disease is necessarily a lengthy process as any attempt at rapid eradication would fail through a shortage of vets to carry out the work and would cause serious depletion of stocks. With a reserve of brucellosis-free animals, eradication can be managed without producing sudden shortages. The National Union of Farmers accepts that the ministry's scheme is the best approach although it is anxious that the compensation figures should be high enough-at the moment it feels that the $£ 30$ a head compensation for slaughter is not adequate because the cost of brucella-free stock to replace the slaughtered cattle is some 15 per cent higher than that for unproven stock.

Progress so far seems encouraging. The introduction of the incentives scheme has already involved 45,000 of the country's 200,000 herds and applications to join the scheme are running at about 1,500 a week. It is thought that these herds are those only lightly or moderately infected and of the 2 million or so animals tested from herds in the scheme there is a failure rate of just over 2 per cent. Due to the compensation to be paid for slaughtered animals it may be in the interests of those farmers with heavily infected herds outside the eradication areas to wait for compulsory eradication. 